\begin{tabular}{|c|c|c|c|c|c|c|}
\hline \multirow{4}{*}{ Impact Factor: } & ISRA (India) & $=3.117$ & SIS (USA) & $=0.912$ & ICV (Poland) & $=6.630$ \\
\hline & ISI (Dubai, UAE & $=0.829$ & РИНЦ (Russia) & $=0.156$ & PIF (India) & $=1.940$ \\
\hline & GIF (Australia) & $=0.564$ & ESJI $(\mathrm{KZ})$ & $=8.716$ & IBI (India) & $=4.260$ \\
\hline & JIF & $=1.500$ & SJIF (Morocco) & $=5.667$ & OAJI (USA) & $=0.350$ \\
\hline
\end{tabular}

\begin{tabular}{|c|c|}
\hline $\begin{array}{l}\text { SOI: } \frac{1.1 / \mathrm{TA}}{} \\
\text { International Sc } \\
\text { Theoretical \& A }\end{array}$ & $\begin{array}{l}S \text { DOI: } 10.15863 / T A S \\
\text { ientific Journal } \\
\text { pplied Science }\end{array}$ \\
\hline p-ISSN: 2308-4944 (print) & e-ISSN: 2409-0085 (online) \\
\hline Year: 2019 Issue: 05 & Volume: 73 \\
\hline Published: 30.05 .2019 & http://T-Science.org \\
\hline
\end{tabular}

Section 13. Geography. History. Oceanology. Meteorology.
QR - Issue

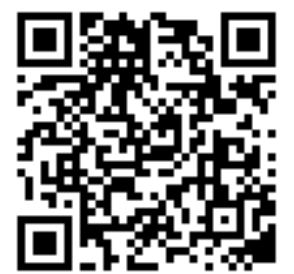

Fazilat Normurodovna Turgunova teacher

National Institute of Arts and Design named after Kamoliddin Behzod

jasur184@list.ru

\title{
HISTORIES OF RESTORATION MEDRESE ULUGBEK IN THE CITY OF SAMARKAND
}

Abstract: In this article the originality of Samarkand architecture and significance for today is considered. The scientific research of scientists and statements, opinions in the field of architecture is analyzed.

Key words: memorial, arch, dome, architectural forms

Language: English

Citation: Turgunova, F. N. (2019). Histories of restoration medrese Ulugbek in the city of Samarkand. ISJ Theoretical \& Applied Science, 05 (73), 445-448.

Soi: $\mathrm{http://s-0-i.org/1.1/TAS-05-73-66} \mathrm{Doi:} \mathrm{crossef} \mathrm{https://dx.doi.org/10.15863/TAS.2019.05.73.66}$

\section{Introduction}

A lot of work is being done to get acquainted with the urban planning monuments in Uzbekistan and around the world and to study the state of modern museums. Nowadays, in the independent Republic of Uzbekistan, great attention is paid to the national values and their restoration, deep analysis of the history of our people, sources of science and culture, as well as archival materials in town-planning monuments, as well as a number of works in the monumental works and bringing these architectural monuments to the next generation is one of today's actual issues.

By the decision of UNESCO in 1990, - The city of Khiva, 1993 -Bukhoro, 2001 - Historical parts of cities such as Samarkand are included in the UNESCO World Cultural Heritage List. They are included in the list of 40 world-class open air museums, and the wide range of architectural monuments reflecting their spiritual and material wealth and their conservation has been widely discussed.

\section{Materials and Methods}

A madrassah and observatory built in Samarkand is one of the most important centers of education and education in the Middle Ages, leading to the city's popularity. The name of this building engineer has not been identified. However, according to the poet Zainiddin Vasifi, who lived in Tashkent for 40 years, the engineer's name was Kamaluddin's engineer, Qizizoda Rumi.
The formation of Registan began in 1417 under the order of the young leader, the construction of a madrasah. The author of the project is the famous Kuvomiddin Sherozi, the master of the palace architect of Shokhrukh (father of Ulugbek), and many architectural complexes built for the khans in Herat. The Ulughbek madrasah is a classic representation of these buildings in the Muslim East in terms of architectural design and quality. Ulughbek madrassah was built in 1417-1420, its height is $81 \times 56$ meters. As we have already noted, only one of the buildings built in Registan in the 15th century, but only one Ulugbek madrassah has been restored to us. In the rooms on the second floor of the Ulughbek madrassa there is a large library of religious and secular science enriching humanity, most of which are collected by great Amir Temur and his children.

From the madrassah of Ulughbek in 1752, Amir Muhammad was used as a non-reservoir in the time of Rahim. Later, in the 19th century, the Ulughbek madrassah was again transformed into a student's educational institution. It was during that period that the repairs of the outer sundeck were carried out. In 1907, almost all of the terraces in the yard were damaged by an earthquake. In the same year a special commission was set up to repair damaged areas. He was appointed to the post of V. L. Vyatkin, but the group under his leadership was ineffective.

The Ulugbek madrassa suffers a lot from the effects of the tsunami, the earthquake, and especially the battle of the 18th century. The outer tower, the dome, two towers, and several mosquitoes were 


\begin{tabular}{llllll} 
& ISRA (India) $=\mathbf{3 . 1 1 7}$ & SIS (USA) $=\mathbf{0 . 9 1 2}$ & ICV (Poland) & $\mathbf{= 6 . 6 3 0}$ \\
Impact Factor: & ISI (Dubai, UAE) $=\mathbf{0 . 8 2 9}$ & PUHЦ (Russia) $=\mathbf{0 . 1 5 6}$ & PIF (India) & $=\mathbf{1 . 9 4 0}$ \\
& GIF (Australia) $=\mathbf{0 . 5 6 4}$ & ESJI (KZ) & $\mathbf{8 . 7 1 6}$ & IBI (India) & $=\mathbf{4 . 2 6 0}$ \\
& JIF & $\mathbf{1 . 5 0 0}$ & SJIF (Morocco) $=\mathbf{5 . 6 6 7}$ & OAJI (USA) & $\mathbf{0 . 3 5 0}$ \\
\hline
\end{tabular}

destroyed. In 1918 the Bukinist book was first discovered that the north-east minaret was sloping, and it fell apart from the main building. Clearly, the tower would be destroyed if no action was taken. Being afraid of falling into the tower of the tower, he decided to inform the VL Vyatkin, an employee of the Samarkand Committee for the Protection of Museums and Monuments of the Ancient Manuscripts. V.Vyatkin was a specialist in monuments protection in Samarkand. In May 1920, a special commission for the reconstruction and restoration of ancient monuments of Samarkand SamKomistaris started its work. The commission consisted of three departments: construction, art and archeology.

It is surrounded by wooden corsets to save a temporary tower. 24 steel ropes with 36 tons are mounted on the wooden anchors to the north-east end of the tower. As a result, the minaret stops and stops at the mark of 108 characters in its normal state.

Regarding the importance of preserving the monument, M. E. Mason said: "The members of the Commission understand that the famous Ulughbek madrassa has great scientific and artistic significance and its façade is unmanageable. In 1870, two castles were destroyed one by one in 1870 .

There are two ways to restore the tower. Mukhtar BN Kastalskiy says the tower is to be rebuilt from the brick. Regional architect MF Mauer has suggested that such a restoration would destroy an ancient monument. Instead, a structure that does not have value is created. Second, the method proposed by M. M. Mauer was to rebuild this tower from the main building. The contention between these two engineers will last long. On June 5, 1920, M.F. Mauer was asked to work quickly. The Commission has entrusted the Technical Department to restore the tower and to carry it out uninterruptedly.

BN Kastalski and M. M. Mauer were invited to attend each meeting at the Commission, from Tashkent, technical advisors from Tashkent. They are more satisfied with Mauer's ideas. Mauer began to learn more about madrassa and began studying Persian.

Mikhail Fyodorovich personally inspects the architectural dimensions of the madrasah in Registan and finds himself in the position of a minaret connected with steel ropes ", wrote M.Masson. At the invitation of M. M. Mauer, a two-stage monument reconstruction project will be considered in Moscow. The first one is left untouched because the information is not complete. In the second half, the project is being developed by the leading Russian engineer Vladimr Grigoryevich Shukhov. Mauer presents this project in agreement with VG Shukhov.

Vukhshukh Shukhov, as well as radios of Shabolov, decorated domes of GUM, Metropolitan, Petrov Passage and some wonderful building workers, have always found an uncertain solution to the Tower of Ulughbek madrasah. This idea was very simple. Overall, it was as follows: to raise the height of the tower with a height of 37 meters and a 2.5 tower ridge, with the rising side of the tower. There is a proposal to fill the gap with concrete when the minaret was restored. This idea was unexpected and inaccessible for A.Kuznetsov's instruction. But Shukhov proved that it was easier to lower the towers than lifting the lift, because it was said that external assistance would not be utilized for the sinking of the building. The second method was to build a minaret from any environmental impact. The idea is being implemented.

In 1927 under the supervision of V.Shukhov under M.F.Mauer project metallic constructions were made from Moscow's "Mostet" plant and sent to Samarkand. These constructions had to be fixed on the base of the tower. Mauer, who looked at the designs, said that these errors would lead to an accident. As a result, he returned to Moscow and managed to overcome the mistakes. By 1931, the deviation of the tower increased by $5.1 \mathrm{~m}$, indicating the risk of its collapse. The gravity center of the tower was moved from the horizontal plane to $1055 \mathrm{~mm}$ relative to the base axis. It was necessary to begin work immediately. The work on the project of Shukhov started.

Before removing the fifteen hinged columns on the tower, the pillars had to be fastened and fixed to the top. This material has been tested. The pillars were fitted with a square-shaped design. Each skeleton that surrounded the structure's tower is 2-4 cm between the iron alibraces. This intermediate water is filled with water vapor. Then it was necessary to secure them to prevent the stem from falling. Each case has a length of $1275 \mathrm{~mm}$, thickness is $89.2 \mathrm{~mm}$, on the other side is $147 \mathrm{~mm}$ and is heavily attached to the stems progons. To keep the pressure uniform, the thicker stepped under the pavement.

The pawns were smashed to the sides of the tower (on the ground floor) to prevent the sinking of the tower and to secure it. These pounds were made of steel cushions with cylinder floors. These pillows are shifted to new locations. The outer pillows are made of thick red currants, as they are firmly rooted in the elm.

All the elements of the constellation have been calculated in a definite way. The minaret's rotation is accomplished by using the tricolor system. A soft tree was lined up underneath them so that the tower was not damaged.

On March 11, 1932, V.Shukhov received a letter from Samarkand from Mauer saying that the minaret was being rebuilt, and it was inserted in the annex as photos were attached to the columns using the design of the frame structure. Thus, the minaret of the madrassa was again rebuilt. 


\begin{tabular}{llllll} 
& ISRA (India) $=\mathbf{3 . 1 1 7}$ & SIS (USA) & $=\mathbf{0 . 9 1 2}$ & ICV (Poland) & $=\mathbf{6 . 6 3 0}$ \\
Impact Factor: & ISI (Dubai, UAE) $=\mathbf{0 . 8 2 9}$ & PUHL (Russia) $=\mathbf{0 . 1 5 6}$ & PIF (India) & $=\mathbf{1 . 9 4 0}$ \\
& GIF (Australia) $=\mathbf{0 . 5 6 4}$ & ESJI (KZ) & $=\mathbf{8 . 7 1 6}$ & IBI (India) & $=\mathbf{4 . 2 6 0}$ \\
& JIF & $\mathbf{1 . 5 0 0}$ & SJIF (Morocco) $=\mathbf{5 . 6 6 7}$ & OAJI (USA) & $\mathbf{0 . 3 5 0}$ \\
\hline
\end{tabular}

Ulugbek madrassah is surrounded by mosaic ornaments, which are made of ceramic plates. This pattern was rebuilt during the 1965 renovation. Blue background patterns are of great beauty in harmony with white and blue colors.

Using the 5-way stars in ornaments on the main portal, their drawing, that is, the technique of creating gyruses, remains a mystery. At the top of the portal, the mosaic panels used a variety of ornamental ornamental patterns. These mosaics are carved from marble stones. It is also one of the peculiarities of the Ulughbek madrassah.

In 1920-26, the main façade of the madrasah was repaired. By 1927, the building was rebuilt as a museum. The southern dome was restored in 1930.

The biggest repairs of the Madrasah were carried out in 1952, according to which the reinforcement of the roof of the building, reconstruction of the main shaft, repairs of the dwellings in the yard and repair of the building were carried out in full.

Under the Gendel project, in 1967, the southsouth tower of the madrassah was rebuilt. According to this, the fortifications of the tower were strengthened and the damaged parts were constructively constructed. The Ulughbek madrassah is surrounded by belts, the reason for which is the collapse of the second building of the building and the disappearing dome of the two sides of the building, and then the large roof can be overthrown. To prevent the roof overturned, pull the cord with crosswalk.

Ulughbek madrassah In October 1977, the building was repaired because of the overflow of water. Accordingly, engineers were given the task to repair the basement of the western wall of the building. Particularly in the north-south part of the western part of the valley was more or less ruined. Because of the damage of the base, it was also necessary to adjust the north-east and south-east towers.

Based on these objectives, the plan for the reconstruction of the Ulugbek madrasa was developed, according to which:

1. Install special equipment for air circulation throughout the Madrasah;

2. Dry dampened areas with these devices;
3. Using traditional and modern methods of repair;

as well as a number of plans.

Coming to the exterior wall of the walls, each region has been thoroughly studied.

By 1977 the outer cover of the tympan was completely renovated. The constructive roof of the roof is parallel to the inscription, which together with the records moved, and 35-40\% were repaired. The southernmost pile of Madrasah is well-preserved, but the bottom marble has been completely redone.

The rest of the rest of the madrasah roof is restored and the rest of the mosaic cover of the upper part of the roof is completely rebuilt. The northern part of the wall is rebuilt like a southern part.

Losses on the main portal of Ulugbek madrasa:

- 95\% of Arabic writings have been lost

- Over $50 \%$ of the top coating of colon-

- 50\% of the Arabic texts on the front of the wall,

- $75 \%$ of decorative backgrounds have been repaired.

Only the first floor had been preserved in the eastern wing of the Northern courtyard. Almost all parts of the outer cover have been reconstructed. The tympanus, that is, the outer coat of canoes and poras almost did not survive.

\section{Conclusion}

In summary, at Ulughbek madrasah, smaller constructive works have been carried out over the years for the type of earthquake and floods and moisture. In the years of independence almost all the places of madrassah are reconstructed. In the period from 2011 to the 12th, the western end of the madrasah was rebuilt. The dome was two-layer, the first of which was a constructive dome, and the second one was decorated with decorative dome, with a distance of 10 meters.

During the years of independence, the Registan Square, including the Ulugbek madrassah, are undergoing major repairs. But in the process of repair, it was desirable to use high quality construction and decoration materials, and to be more careful about the quality of the work, which would help to present the architectural pearls to the future generations.

\section{References:}

1. Kryukov, K. S. (1970). Registan. Pamyatnik arkhitektury. Tashkent.

2. Aleskerov, Y. N. (1974). Samarkand. Izdatel"stvo Uzbekistana. Tashkent.
3. Bartol'd, V. V. (1915). Ulugbek i ego vremya. Tashkent.

4. Pletnev, I. E. (1920). Obosnovanie $k$ proektu restavratsii soffitov glavnogo portala Ulugbeka. Tashkent. 


\begin{tabular}{|c|c|c|c|c|c|c|}
\hline \multirow{4}{*}{ Impact Factor: } & ISRA (India) & $=3.117$ & SIS (USA) & $=0.912$ & ICV (Poland) & $=6.630$ \\
\hline & ISI (Dubai, UAE & $=0.829$ & РИНЦ (Russia) & $=0.156$ & PIF (India) & $=1.940$ \\
\hline & GIF (Australia) & $=0.564$ & ESJI (KZ) & $=8.716$ & IBI (India) & $=4.260$ \\
\hline & JIF & $=1.500$ & SJIF (Morocco) & $=5.667$ & OAJI (USA) & $=0.350$ \\
\hline
\end{tabular}

5. Bartol'd, V. V. (1963). Istoriya kul'turnoy zhizni Turkestana.

6. Semenov, A. A. (1928). Nekotorye osobennosti material'noy kul'tury proshlykh epokh Sredney Azii. Izvestiya Sredazkomstarisa. Vyp. 1.

7. Lunin, B. V. (1958). Iz istorii russkogo vostokovedeniya $i$ arkheologii $v$ Turkestane. Tashkent.

8. Lunin, B. V. (1962). Nauchnye obshchestva Turkestana i ikh progressivnaya deyatel'nost'. Tashkent.
9. (1994). Medrese Ulugbeka v g. Samarkande. Al'bom Fotoillyustratsiy. 1994. Y̌zR MV Madaniy meros departamenti zhoriy arkhivi. A90-fond.

10. (1992). Medrese Ulugbeka v.g. Samarkande. Y̌zR MV Madaniy meros departamenti zhoriy arkhivi. Sh-69-fond. Kniga A. 1-1. Toshkent.

11. Masson, M. E. (1929). Registon i ego medrese. Samarkand. 